\title{
In vitro adhesiveness and biotype of Gardnerella vaginalis strains in relation to the occurrence of clue cells in vaginal discharges
}

\author{
THOMAS G SCOTT,* CYRIL J SMYTH, $\dagger$ AND CONOR T KEANE $\ddagger$
}

From the *Department of Biological Sciences, Dublin Institute of Technology, the $\dagger$ Department of Microbiology, Moyne Institute, Trinity College, and the $\ddagger$ Department of Clinical Microbiology, St James's Hospital, Dublin, Republic of Ireland

SUMMARY Haemagglutination and tissue culture adherence tests using a McCoy cell line were used to examine the adherence characteristics of 105 strains of Gardnerella vaginalis. Each strain represented one isolate per patient. For each patient, a direct smear of vaginal discharge was examined for clue cells. The relation between in vitro adherence and the presence of clue cells was examined. There seemed to be no appreciable relation between the presence of clue cells in smears and the haemagglutinating activity of strains. In contrast, adherence as judged by the McCoy tissue culture system showed a significant relation to the presence of clue cells $(p<0.001)$. Though both adhesive characteristics were not inhibited by mannose, the mechanism of haemagglutination of human red cells appeared to differ from that of adherence of tissue culture cells. The findings imply that the clue cell phenomenon is due to attachment of adherent strains of $G$ vaginalis to epithelial cells. Adherent strains of $G$ vaginalis may play a part in the pathogenesis of bacterial vaginosis.

\section{Introduction}

Gardner and Dukes in an investigation of bacterial vaginosis (non-specific vaginitis) claimed that Gardnerella vaginalis (Haemophilus vaginalis) was the sole aetiological agent of this condition. ${ }^{1}$ This claim became a matter of controversy, and some investigators supported the role of the organism in the aetiology of bacterial vaginosis, ${ }^{2-7}$ whereas others found no relation. ${ }^{8-11}$ It is widely accepted, however, that $G$ vaginalis is often isolated from the normal vaginal flora. ${ }^{9-11}$ Recent investigations have shown an increased association between anaerobes, $G$ vaginalis, and bacterial vaginosis. . $^{3-5} 1113$ The condition is now usually considered to be a polymicrobial infection.

The finding of epithelial cells coated with bacteria in the vaginal discharge of bacterial vaginosis was first reported by $\mathrm{Gardner}$ and Dukes. ${ }^{1}$ These cells were called clue cells. The finding of clue cells has since been a common feature of many studies of bacterial

\footnotetext{
Address for reprints: Mr T G Scott, Department of Biological Sciences, Dublin Institute of Technology, Kevin Street, Dublin, Republic of Ireland

Accepted for publication 5 May 1986
}

vaginosis. ${ }^{13-15}$ The presence of cells coated with Gram variable bacilli seems to indicate an association with adhesive strains of Gardnerella spp. Comprehensive studies have been carried out on the adhesive properties of many organisms. ${ }^{16}$ There has, however, been relatively little investigation of the adhesiveness of $G$ vaginalis. Haemagglutination activity was first described by Edmunds. ${ }^{17}$ Mardh and Weström showed that $G$ vaginalis had a higher adherence rate than bacteria thought to belong to the indigenous vaginal flora. ${ }^{18}$ Sobel et al showed that adherence of $G$ vaginalis to vaginal epithelial cells collected at various stages of the menstrual cycle did not vary, and that adherence to vaginal epithelial tissue culture cells was comparable to adherence to exfoliated vaginal epithelial cells. ${ }^{19} 20$

In the present investigation the adhesiveness of several strains of $G$ vaginalis was studied by assessing (1) haemagglutinating properties for a range of species of red cells and (2) adhesive properties for an epithelial tissue culture line (McCoy). The results were analysed to establish whether a relation existed between the adhesiveness of the organism (as judged by standardised in vitro tests) and the presence of clue cells in the vaginal discharge. The biotype was also established to ascertain whether there was any relation between adhesiveness and biotype. 


\section{Patients, materials, and methods}

\section{STUDY POPULATION}

The strains of $G$ vaginalis examined were recovered from routine high vaginal swabs from 105 patients. These were obtained from the Coombe Maternity Hospital, Dublin, and St James's Hospital, Dublin (general and maternity). Neisseriae, Candida spp, or Trichomonas vaginalis were not recovered from these patients. Of the 105 strains acquired, 41 (39\%) were from antenatal and postnatal patients, $44(42 \%)$ were from gynaecological patients, 12 (11\%) were from patients attending general practitioners and family planning clinics, and eight $(8 \%)$ were from patients attending sexually transmitted disease (STD) clinics. Each strain was received with a direct Gram stained smear of the vaginal discharge.

\section{ISOLATION AND CULTURE CONDITIONS}

The strains were isolated from high vaginal swabs using Casman agar (Difco) with $5 \%$ human blood and containing gentamicin $4 \mathrm{mg} / \mathrm{l}$, nalidixic acid $30 \mathrm{mg} / \mathrm{l}$ and amphotericin B $2 \mathrm{mg} / \mathrm{l}$ as selective agents. From the primary isolation plate $5-10$ colonies of Gardnerella like organisms were pooled and subcultured for identification. Strains identified as $G$ vaginalis were further subcultured by inoculating 510 colonies on to Casman agar with $5 \%$ human blood added. About five colonies of similar colonial morphology were pooled and subcultured as stock strains.

In eight cases, two distinct colonial types were observed and these were subcultured separately. These variants showed differences in colony size and haemolytic properties. The term strain as used in this report indicates a representative population of $G$ vaginalis organisms of similar colonial morphology from a patient. The strains were identified according to the scheme of Taylor and Phillips. ${ }^{21}$ In addition, strains were biotyped according to the system of Piot $e t$ al. 22 Strains were grown on Casman blood agar (Difco) for 48 hours at $37^{\circ} \mathrm{C}$ in about $5 \%$ carbon dioxide (GasPak, BBL) and were subcultured every 48 hours. Broth culture was in thiogylcollate broth (Oxoid), supplemented with $1 \%(\mathrm{w} / \mathrm{v})$ proteose peptone (Difco) and 7\% (v/v) horse serum (Burroughs Wellcome). All isolates were stored according to the method of Taylor and Phillips ${ }^{21}$ in thioglycollate broth containing $10 \%(\mathrm{v} / \mathrm{v})$ glycerol and $10 \%(\mathrm{v} / \mathrm{v})$ defibrinated horse blood. The strains were stored at $-20^{\circ} \mathrm{C}$.

\section{HAEMAGGLUTINATION TESTS}

The erythrocytes used were human group 0 , chick, sheep, and horse cells. The chick blood was obtained from the Veterinary Research Laboratory, Abbotstown, County Dublin, and the sheep and horse blood was obtained from Biological Laboratories, Ballina, County Mayo, Eire. Blood was stored at $4^{\circ} \mathrm{C}$ for one week. Bacterial suspensions of about $5 \times 10^{10}$ organisms $/ \mathrm{ml}$ were prepared in phosphate buffered saline (PBS) $(0.15 \mathrm{~mol} / 1$ sodium chloride with 0.01 mol/l sodium phosphate buffer, $\mathrm{pH}$ 6.8) from 48 hour cultures on Casman blood agar. This suspension was used in both the rocked tile and microhaemagglutination titration tests.

The rocked tile test was performed according to the method of Duguid et al. ${ }^{23}$ A $3 \%$ (v/v) packed red cell suspension was used. Tests were carried out in parallel in PBS and $0.1 \mathrm{~mol} / 1$ mannose in PBS. The bacteria were found to react poorly at room temperature (18$20^{\circ} \mathrm{C}$ ) and were subsequently tested at $0^{\circ} \mathrm{C}$. The results were graded $+++($ strong reaction occurring in seconds), ++ (large clumps in about one minute), + (clumps in about two minutes), \pm (granular appearance after two minutes), or - (negative reaction). For the microhaemagglutination tests, the same suspension of bacteria as for the tile test was used but the red cell suspension was $1 \%(\mathrm{v} / \mathrm{v})$ packed cells. The tests were carried out in round bottomed plastic microtitre trays. The bacteria were diluted in a twofold series $(25 \mu \mathrm{l})$ in PBS and in $0.1 \mathrm{~mol} / \mathrm{l}$ mannose in PBS, and an equal volume of red blood cells was added to each well. Incubation was at $4^{\circ} \mathrm{C}$ overnight. The haemagglutination titre was recorded as the highest twofold dilution of bacterial suspension giving a carpet of erythrocytes over the bottom of a well.

\section{TISSUE CULTURE ADHERENCE}

McCoy cells, an epithelial cell line derived from human synovial membrane, ${ }^{24}$ were supplied by the microbiology department, St James's Hospital, Dublin. These were maintained in Earle's medium 100 (Flow Laboratories Ltd, Irvine, Scotland) supplemented with: $1 \%(\mathrm{v} / \mathrm{v})$ non-essential amino acids (Flow), 1\% (v/v) L-glutamine $200 \mathrm{mmol} / 1$ (Flow), $10 \%(\mathrm{v} / \mathrm{v})$ fetal calf serum (Flow), $200 \mathrm{mg} / \mathrm{l}$ streptomycin, $40 \mathrm{mg} / \mathrm{l}$ mycostatin, and $0.4 \mathrm{~mol} / 11 \%$ (v/v) sodium bicarbonate.

Tissue cultures were subcultured by trypsinising monolayers with $0.25 \%(w / v)$ trypsin. The cells were resuspended in complete growth medium. Cells were counted, and the cell concentration was adjusted to $3 \mathbf{x}$ $10^{5}$ cells $/ \mathrm{ml}$. Of this cell suspension, $1 \mathrm{ml}$ aliquots were added to Trac tubes (Sterilin, Feltham, England), each of which contained a prewashed and sterilised $13 \mathrm{~mm}$ diameter No 3 circular coverslip (Chance Propper, Smethwick, England). The preparations were incubated for 18-20 hours until subconfluent growth was obtained.

Bacteria for adherence studies were cultured on Casman blood agar for 48 hours at $37^{\circ} \mathrm{C}$ in carbon dioxide. Five strains were grown in thioglycollate broth for 48 hours at $37^{\circ} \mathrm{C}$, harvested by centrifugation, 
and washed once with PBS. Suspensions of $1 \times 10^{8}$ bacteria/ml in Dulbecco-A PBS (pH 7.2) were prepared by an opacity tube method. For each test, $1 \mathrm{ml}$ of suspension was added to the Trac tube from which growth medium had been removed. This was incubated at $37^{\circ} \mathrm{C}$ for one hour. The bacterial suspension was removed, and the monolayer was washed five times in Dulbecco-A PBS. The preparation was fixed in methanol, stained with $10 \%$ Giemsa for 30 minutes, washed in tap water, and decolourised in acidified tap water. The preparation was dehydrated in acetone and cleared in xylene. The coverslip preparation was stuck on to a glass slide with monolayer uppermost using DPX (Gurr). This was then mounted in DPX using a circular No $1 \frac{1 / 2}{2}$ coverslip (Chance Propper). The complete preparation was examined under an oil immersion lens for the presence of adherent bacteria.

The effect of mannose on bacterial adherence to McCoy cells was tested by suspending bacteria in $0 \cdot 1$ $\mathrm{mol} / \mathrm{l}$ mannose in Dulbecco-A PBS. The suspension was incubated at $37^{\circ} \mathrm{C}$ for 30 minutes before being added to McCoy monolayers. Because of the clumping of bacteria and the fact that attachment occurred at different planes, it was not possible to count accurately the numbers of bacteria attached to individual cells of the tissue culture monolayer. To determine an adhesive index, a total of 200 cells from several fields was counted and the number of tissue culture cells with adherent bacteria was calculated as a percentage.

\section{EXAMINATION FOR CLUE CELLS}

The Gram stained preparations of vaginal discharges were examined for evidence of clue cells. All smears that showed Gram variable bacteria attaching in large numbers to epithelial cells were recorded as giving positive results.

\section{SCANNING ELECTRON MICROSCOPY}

McCoy cell preparations showing bacterial adhesion were examined by scanning electron microscopy. The preparations were fixed in $3 \%(\mathrm{v} / \mathrm{v})$ glutaraldehyde in $0.01 \mathrm{~mol} / 1$ cacodylate buffer $\mathrm{pH} 7 \cdot 2$, dehydrated, and critical point dried in a Balzers CPS-200. The coverslip was attached using carbon cement, sputter gold coated using an Emscope SC-500, and viewed in a Hitachi 3520 scanning electron microscope.

STATISTICAL ANALYSIS

Results were analysed by the $X^{2}$ test.

\section{Results}

HAEMAGGLUTINATION

The haemagglutining activity was strongest with
TABLE I Haemagglutinating properties of 105 strains of Gardnerella vaginalis against four types of red blood cells in the rocked tile test

\begin{tabular}{lcccc}
\hline \multicolumn{5}{c}{$\begin{array}{l}\text { No (\%) of strains giving indicated } \\
\text { strength of reaction with (red blood cells): }\end{array}$} \\
\cline { 2 - 6 } $\begin{array}{l}\text { Strength of } \\
\text { reaction }\end{array}$ & Human 0 & Chick & Sheep & Horse \\
\hline+++ & $9(8 \cdot 6)$ & & & \\
++ & $31(29 \cdot 5)$ & $6(5 \cdot 7)$ & & \\
+ & $35(33 \cdot 3)$ & $36(34 \cdot 3)$ & $4(3 \cdot 8)$ & $4(3 \cdot 8)$ \\
\pm & $21(20)$ & $40(38 \cdot 1)$ & $36(34 \cdot 3)$ & $34(32 \cdot 4)$ \\
+ & $9(8 \cdot 6)$ & $23(21 \cdot 9)$ & $65(61 \cdot 9)$ & $67(63 \cdot 8)$ \\
\hline
\end{tabular}

$+++=$ Strong reaction in seconds.

$++=$ Large clumps in about one minute.

$t=$ Clumps in about two minutes.

$\pm=$ Granular appearance after two minutes.

$-=$ No reaction.

human group 0 cells, the reaction with chick cells was slightly weaker, and only minimal activity was detected against sheep and horse cells (table I). The haemagglutination reactions were not inhibited by mannose. In the tile test, haemagglutination eluted at $37^{\circ} \mathrm{C}$, but recurred without loss of activity on cooling at $0^{\circ} \mathrm{C}$. The rocked tile test was less sensitive than the microtitre test in detecting haemagglutinating activity (tables I and II). The haemagglutination properties of the colonial variants detected in the eight patients were identical.

TABLE II Haemagglutinating properties of 105 strains of Gardnerella vaginalis against four types of red blood cells in the microtitre test

\begin{tabular}{lllll}
\hline & \multicolumn{4}{l}{$\begin{array}{l}\text { No (\%) of strains haemagglutinating } \\
\text { at indicated titre with (red blood cells): }\end{array}$} \\
\cline { 2 - 5 } Titre & Human 0 & Chick & Sheep & Horse \\
\hline $1 / 16$ & $10(9 \cdot 5)$ & & & \\
$1 / 8$ & $34(32 \cdot 4)$ & $12(11 \cdot 4)$ & & \\
$1 / 4$ & $39(37 \cdot 1)$ & $38(36 \cdot 2)$ & $16(15 \cdot 2)$ & $20(19)$ \\
$1 / 2$ & $22(21)$ & $38(36 \cdot 2)$ & $45(42 \cdot 9)$ & $46(43 \cdot 8)$ \\
ND & & $17(16 \cdot 2)$ & $44(41 \cdot 9)$ & $39(37 \cdot 1)$ \\
\hline
\end{tabular}

*Highest twofold dilution of bacterial suspension giving carpet of red blood cells in microtitre tray well.

ND $=$ Not detected with undiluted suspension.

No correlation was found between the presence of haemagglutinin on strains, as detected by the semiquantitative tile and quantitative microtitre methods, 
and the presence of clue cells in Gram stained smears of the respective vaginal discharges from which the isolates were obtained (table III). For the purpose of comparison, colonial variants were treated as one strain.

TABLE III Correlation of haemagglutinating activity of 105 Gardnerella vaginalis strains against human $O$ cells with presence of clue cells in smears of vaginal discharges

\begin{tabular}{llccc}
\hline $\begin{array}{l}\text { Haemaggluti- } \\
\text { nation } \\
\text { test }\end{array}$ & $\begin{array}{l}\text { Reaction } \\
\text { strength } \\
\text { or titre }\end{array}$ & $\begin{array}{l}\text { No with } \\
\text { clue cells } \\
(\boldsymbol{n}=58)\end{array}$ & $\begin{array}{l}\text { No with no } \\
\text { clue cells } \\
(\boldsymbol{n}=47)\end{array}$ & Total \\
\hline Rocked tile* & +++ & 3 & 6 & 9 \\
& ++ & 17 & 14 & 31 \\
& + & 17 & 18 & 35 \\
& \pm & 15 & 6 & 21 \\
& - & 6 & 3 & 9 \\
Microtitre* $^{*}$ & $1 / 16$ & 7 & 3 & 10 \\
& $1 / 8$ & 17 & 17 & 34 \\
& $1 / 4$ & 19 & 20 & 39 \\
& $1 / 2$ & 15 & 7 & 22 \\
\hline
\end{tabular}

*Comparison of distribution of isolates on basis of strength or titre of haemagglutinating activity with presence or absence of clue cells: tile test, $x^{2}(4 \mathrm{df})=0.2>\mathrm{p}>0 \cdot 1 ;$ microtitre test, $x^{2}(3 \mathrm{df})=$ $0.5>\mathrm{p}>0.2$.

\section{TISSUE CULTURE ADHESION}

There was considerable variation in the ability of strains to attach to McCoy cells. A cell was deemed to have adherent bacteria present when more than a few organisms were seen to be attached, and no free bacteria were observed in the intercellular spaces (figure (a)). The most adherent strains attached heavily to all cells (figure (b)). The adherence properties did not seem to be affected by subculture, as strains retained their adherence index throughout numerous subcultures. The culture of strains in thioglycollate broth did not alter the adherence capacity of organisms, and adherence was not inhibited by mannose. Scanning electron microscopy of tissue culture preparations with adherent bacteria confirmed that attachment was to the cell membrane.

Of the $105 G$ vaginalis strains, $46(43 \%)$ showed an adherence index greater than $20 \%$. Of these 46 adherent strains, $15(14 \%)$ had an adherence index of $21-40 \%$, nine $(9 \%)$ had an adherence index of 41 $60 \%$, nine $(9 \%)$ had an adherent index of $61-80 \%$, and $13(12 \%)$ had an adherence index of $81-100 \%$. Colonial variants were found to have the same adherence index and were treated as one strain for the purpose of correlative analysis. When the adherence property (as judged by tissue culture adhesiveness) was compared with microhaemagglutination activity, no correlation was observed (table IV). When the tissue culture adherence index was compared with the presence of clue cells in patients' vaginal smears, a significant correlation $\left(X^{2}\right.$ test $\left.p<0.001\right)$ was found between in vitro adhesiveness and the presence of clue cells (table V).

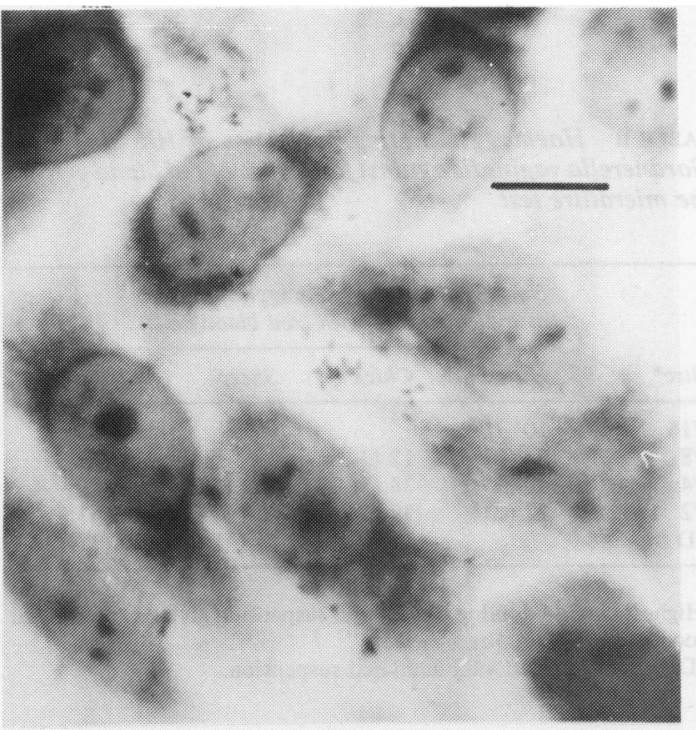

a

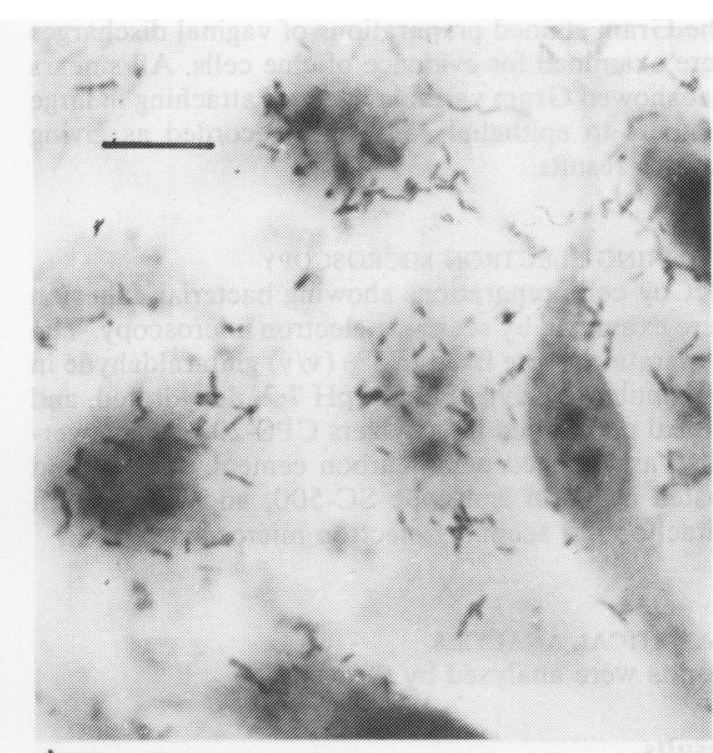

b

FIGURE Adherence of Gardnerella vaginalis to McCoy tissue culture cell monolayers: (a) moderate attachment of bacteria to several tissue culture cells, (b) heavy attachment of bacteria to most cells. (Giemsa.) (Bars=10 $\mu \mathrm{m}$.) 
TABLE IV Tissue culture adherence index correlated to microhaemagglutination titre for human $O$ cells of 105 Gardnerella vaginalis strains

\begin{tabular}{lll}
\hline \multirow{2}{*}{$\begin{array}{l}\text { Tissue culture adhesion } \\
\text { index }(\%)^{*} \dagger\end{array}$} & \multicolumn{2}{l}{ Microhaemagglutination titre of: } \\
\cline { 2 - 3 } & $1 / 2-1 / 4$ & $1 / 8-1 / 6$ \\
\hline $0-20$ & 30 & 29 \\
$21-100$ & 31 & 15 \\
\hline
\end{tabular}

*Percentage of McCoy tissue culture cells with adherent bacteria. + Comparison of $\%$ adherence index with microhaemagglutination titre of strains, $2 \times 2$ contingency test, $x^{2}=0.2>p>0.5$.

\section{BIOTYPING}

The $G$ vaginalis strains were biotyped and the distribution of biotypes was found to be: biotype 1 in $51 \%(53)$, biotype 2 in $20 \%(21)$, biotype 3 in $2 \%$, biotype 4 in $2 \%$, biotype 5 in $18 \%$ (19), biotype 6 in $6 \%$, biotype 7 in $1 \%$, and biotype 8 in $1 \%$. This distribution was similar to that reported by Piot et al.$^{25}$ Colonial variants of strains were found to be of the same biotype. There seemed to be no difference in the level of adhesiveness among strains of the three major biotypes found in this study and by Piot et al, ${ }^{25}$ in that $40 \%$ of biotype $1,39 \%$ of biotype 2 , and $48 \%$ of biotype 5 strains showed an adhesive index of more than $20 \%$.

\section{INCIDENCE OF ADHESIVE STRAINS IN PATIENT GROUPS}

The incidences of strains showing an adherence index of $20 \%$ or more among the patient populations studied were: $37 \%$ for the antenatal and postnatal patients, $42 \%$ for the gynaecological patients, $50 \%$ for the patients from general practitioners and family planning

TABLE V Correlation of tissue culture adherence index of 105 Gardnerella vaginalis strains with the presence of clue cells in smears of vaginal discharges

\begin{tabular}{llll}
\hline $\begin{array}{l}\text { Adherence index } \\
\text { of isolates } \\
(\%)^{*}+\end{array}$ & $\begin{array}{l}\text { No with } \\
\text { clue cells }\end{array}$ & $\begin{array}{l}\text { No with no } \\
\text { clue cells }\end{array}$ & Total \\
\hline $0-20$ & 19 & 40 & 59 \\
$21-100$ & 39 & 7 & 46 \\
\hline
\end{tabular}

*Distribution of isolates on the basis of adherence index compared with the presence or absence of clue cells: $2 \times 2$ contingency test, $\chi^{2}=\mathrm{p}<0.001$.

+ No of strains with more than $20 \%$ adhesion in patients with clue cells: $21-40 \%(13), 41-60 \%(8), 61-80 \%(7)$ and $81-100 \%(11)$; and in patients without clue cells: $21-40 \%(2), 41-60 \%$ (1), 61-80\% (2), and $81-100 \%(2)$. clinics, and $75 \%$ for the patients attending (STD) clinics. The differences in incidence between patient populations were not significant.

\section{Discussion}

The finding that $G$ vaginalis can be present in the vaginal flora of apparently healthy women has led to great difficulty in interpreting its role in bacterial vaginosis. The possibility that quantitative recovery methods might be useful has been evaluated by a number of workers. Some found an association between bacterial vaginosis and increased vaginal concentrations of $G$ vaginalis compared with healthy women, ${ }^{47}$ but others found no such association. ${ }^{1012}$ Among the reasons for the conflict in findings could be the difficulty in standardising sampling and the method used for clinical evaluation of the condition. There is, however, consistent evidence that $G$ vaginalis is isolated more often from patients with bacterial vaginosis than from healthy controls. ${ }^{3-7}$ The usually accepted current criteria for bacterial vaginosis are homogeneous secretions with a $\mathrm{pH}$ of more than $4 \cdot 5$, a fishy odour on adding $10 \%$ potassium hydroxide to secretions, and the presence of clue cells. Though the last criterion is not associated with all cases of bacterial vaginosis, a number of workers have found a high level of correlation, particularly when Gram stain was used to detect clue cells. ${ }^{13-15}$

In the present study in vitro tests for adhesiveness were carried out to establish whether differences existed in the adhesive properties of $G$ vaginalis strains. We thought that the clue cell phenomenon was more likely to be due to the adhesive ability of the organism than merely to bacterial load. An attempt was therefore made to correlate the findings of the in vitro adhesion study to the presence of clue cells in patients. The in vitro tests used might be thought to be somewhat artificial and not truly reflective of in vivo conditions. However, they provide rapid, simple, and standardised model systems to permit the evaluation of putative adhesive properties of bacteria. ${ }^{25}$

When the adherence index of strains was compared with the presence of clue cells in smears of patients' vaginal discharges, a significant correlation was found. Though the correlation does not absolutely prove that the mechanism of adhesion to the McCoy cell line and vaginal epithelial cells are identical, the findings provide sufficient basis for the use of the McCoy cells as a model for investigating molecular aspects of the adhesiveness of $\boldsymbol{G}$ vaginalis. Questions of the appropriateness of the use of an epithelial tissue culture line are outweighed by the problem associated with the uncontrolled variables arising from the use of exfoliated and possibly non-viable vaginal epithelial cells in a study such as this. 
The strains used in this study constituted pools of typical $G$ vaginalis colonies from individual primary isolation plates. The question now arises of whether the adherence indexes of these strains are a measure of the adhesiveness of homogeneous populations of bacteria or whether they reflect the relative presence of adhesive organisms within heterogeneous populations. Though in the small number of colonial variants found no differences in the adherence index were apparent, an intensive investigation of the adhesiveness of multiple single colony isolates from individuals would be required to distinguish between the above possibilities.

The results of the haemagglutination studies showed that the strongest reaction was with human red cells. The titres produced were restricted to a narrow range. The finding that adhesiveness (as determined by haemagglutination) did not correlate with the presence of clue cells in patients' vaginal smears suggests that haemagglutinin may not be appreciably adhesive in vivo. No important correlation between haemagglutination titre and tissue culture adhesiveness was found, which indicated that separate adherence mechanisms may be implicated.

Many bacteria that attempt to colonise mucosal epithelial surfaces have adherent properties. Though adherence may be necessary to establish commensal states, pathogenic organisms must compete with normal flora. Enhanced adhesiveness would therefore be an important characteristic for the development and maintenance of infective states. ${ }^{26}$ The correlation between the adherence index and the presence of clue cells in patients' smears suggests that clue cell formation is associated with adherent strains of $G$ vaginalis. This does not, however, provide direct evidence of a causative role for adherent strains of $G$ vaginalis in bacterial vaginosis. Nevertheless, because of the reported incidence of clue cells in smears from women with the condition, the adherent properties of $G$ vaginalis may have a bearing on the pathogenesis of the condition.

In a study of adhesiveness in group B streptococci, Botta established that adhesive strains were predominantly of serotype III, which is the most common serotype in infections. ${ }^{27}$ In the present study biotyping was carried out, but no appreciable difference could be found in the adherence index of organisms of the major biotypes. This agrees with the findings of Piot et al, who found that there was no appreciable relation between biotypes and bacterial vaginosis. ${ }^{22}$ Also, in our study we found no difference in the occurrence of adhesive strains in most of the groups of patients tested, but six of the eight patients from STD clinics yielded $G$ vaginalis isolates with an adhesive index of more than $20 \%$. Because our sample was small, however, the results warrant further investigation to assess their clinical importance.
Apart from its role in bacterial vaginosis, $G$ vaginalis has been increasingly reported to be implicated in invasive infections, neonatal sepsis, and neonatal and maternal bacteraemia. ${ }^{28-31}$ The organism has also been reported in apparently "abacterial" pyurias. $^{32-34}$ In a study of unconventional bacteria in patients with "sterile" pyelonephritis, Fairley and Birch found $G$ vaginalis in $33 \% .{ }^{35}$ They reported the presence of epithelial cells, apparently coated with $G$ vaginalis, in most of the patients and commented on their similarity to clue cells. These findings indicate a need to study the adhesive properties of $G$ vaginalis isolated from invasive and non-vaginal infections.

The mechanism by which $G$ vaginalis attaches to epithelial cells has not as yet been elucidated, but the presence of fimbriae on $G$ vaginalis has been recorded.$^{36}$ In a recent report on the haemagglutinating properties of $G$ vaginalis, Ison and Easmon showed that haemagglutination was not sensitive to mannose, but was inhibited by D-galactose and D-galactosamine, and that treating the red cells with sodium periodate reduced haemagglutination. ${ }^{37}$ This indicated that there is possibly a carbohydrate receptor on the red cell. The failure in the present study to correlate haemagglutination with tissue culture adhesion, however, seems to indicate a different combination of adhesion and receptor in the attachment of $G$ vaginalis to epithelial cells. Indeed, though the haemagglutinating activity of strains is inhibited by D-galactose and D-galactosamine, the tissue culture adherence of the same strains is resistant to both (Scott TG, unpublished observations). Investigation of the mechanism of adhesion of $G$ vaginalis to tissue culture cells, as a model for the attachment to vaginal epithelial cells, is currently under way.

The findings of the report published here show clearly that adhesiveness varies considerably between strains of $G$ vaginalis. The relation shown between the presence of clue cells in vaginal smears and tissue culture adhesiveness indicates a possible role for adherent strains in the pathogenesis of bacterial vaginosis. Further evaluation of the relevance of the McCoy cell adherence test is now required to establish the incidence of adherent strains from patients with bacterial vaginosis, evaluated by currently acceptable criteria, compared with the incidence from patients without symptoms of bacterial vaginosis. The effect of metronidazole treatment on the recovery of adherent strains would also be of particular interest.

We thank Ms Anne-Marie Bermingham of the Coombe Maternity Hospital and the microbiology staff of St James's Hospital, Dublin, for their co-operation in obtaining isolates of $G$ vaginalis; Dr D John of the electron microscopy unit, Trinity College, Dublin, for scanning electron microscopy studies; Ms Angela Rossney for advice on tissue culture; and Mrs Mary Foody for typing the manuscript. 


\section{References}

1. Gardner HL, Dukes $C D$. Haemophilus vaginalis vaginitis. A newly defined specific infection previously classified "nonspecific vaginitis". Am J Obstet Gynecol 1955;69:962-76.

2. Lewis JF, O'Brien SM, Ural UM, Burke T. Corynebacterium vaginale vaginitis. Am J Obstet Gynecol 1972;112:87-90.

3. Pheifer TA, Forsyth PS, Durfee MA, Pollock HM, Holmes KK. Non-specific vaginitis. $N$ Engl J Med 1978;298:142934.

4. Spiegel CA, Amsel R, Eschenbach D, Schoenknecht F, Holmes KK. Anaerobic bacteria in non-specific vaginitis. $N$ Engl J Med 1980;303:601-7.

5. Taylor E, Blackwell AL, Barlow D, Phillips I. Gardnerella vaginalis, anaerobes and vaginal discharge. Lancet 1982; i: 1376-9.

6. Amsel R, Totten PA, Spiegel CA, Chen KCS, Eschenbach D, Holmes KK. Non-specific vaginitis: diagnostic criteria and microbial and epidemiological associations. $\mathrm{Am} \mathrm{J} \mathrm{Med}$ 1983;74:14-22.

7. Speigel CA, Davick P, Totten PA, et al .Gardnerella vaginalis and anaerobic bacteria in the etiology of bacterial (non-specific) vaginosis. Scand J Infect Dis [Suppl] 1983;40:41-6.

8. Dunkelberg WE, Hefner JD, Patow WE, Wyman FJ, Orup HI. Haemophilus vaginalis among asymptomatic women. Obstet Gynecol 1962;20:629-32.

9. McCormack WM, Hayes $\mathrm{CH}$, Rosner B, et al. Vaginal colonization with Corynebacterium vaginale (Haemophilus vaginalis. $J$ Infect Dis 1977;136:740-5.

10. Levison ME, Trestman I, Quach R, Sladowski C, Floro CN. Quantitative bacteriology of the vaginal flora in vaginitis. $A m \mathrm{~J}$ Obstet Gynecol 1979;133:139-44.

11. Fredricsson B, Hagstrom B, Evaldson G, Nord C-E. Gardnerella associated vaginitis and anaerobic bacteria. Gynecol Obstet Invest 1984;17:236-41.

12. Wilks $M$, Thin RN, Tabaqchali S. Quantitative bacteriology of the vaginal flora in genital disease. $J$ Med Microbiol 1984;18:217-31.

13. Piot $\mathbf{P}$, Van Dyck $E$, Godts $\mathbf{P}$, Vanderheyden J. The vaginal microbial flora in non-specific vaginitis. Euro J Clin Microbiol 1982;1:301-6.

14. Brewer J, Halpem B, Gary T. Haemophilus vaginalis vaginitis. Am J Obstet Gynecol 1957;74:834-43.

15. Spiegel CA, Amsel R, Holmes KK. Diagnosis of bacterial vaginosis by direct $\mathrm{Gram}$ stain of vaginal fluid. $J$ Clin Microbiol 1983;18:170-7.

16. Jones GW. Attachment of bacteria to the surfaces of animal cells. In: Beachey EH, ed. Bacterial adherence. London: Chapman and Hall, 1980:141-70. (Receptors and recognition series B; vol 6.)

17. Edmunds PN. The biochemical, serological and haemagglutinating reactions of Haemophilus vaginalis. Joumal of Pathology and Bacteriology 1962;83:411-22.
18. Mårdh P-A, Weström L. Adherence of bacteria to vaginal epithelial cells. Infect Immun 1976;13:661-6.

19. Sobel JD, Schneider J, Kaye D, Levison ME. Adherence of bacteria to vaginal epithelial cells at various times in the menstrual cycle. Infect Immun 1981;32:1194-7.

20. Sobel JD, Myers P, Levison ME, Kaye D. Comparison of bacterial and fungal adherence to vaginal exfoliated epithelial cells and human vaginal epithelial tissue culture cells. Infect Immun 1981;35:697-701.

21. Taylor E, Phillips I. Identification of Gardnerella vaginalis. J Med Microbiol 1983;16:83-92.

22. Piot P, Van Dyck E, Peeters M, Hale J, Totten PA, Holmes KK. Biotypes of Gardnerella vaginalis. J Clin Microbiol 1984;20:677-9.

23. Duguid JP, Clegg S, Wilson MI. The fimbrial and non-fimbrial haemagglutinins of Escherichia coli. J Med Microbiol 1979;12:213-27.

24. Evans RT, Woodland RM. Detection of chlamydiae by isolation and direct examination. Br Med Bull 1983;39:181-6.

25. Freter R, Jones GW. Models for studying the role of bacterial attachment in virulence and pathogenesis. Rev Infect Dis 1983;5 (suppl 4):S647-58.

26. Sparling PF. Bacterial virulence and pathogenesis: an overview Rev Infect Dis 1983;5 (suppl 4):S637-46.

27. Botta G. Hormonal and type dependent adhesion of group B streptococci to human vaginal cells. Infect Immun 1979;25:1084-6.

28. Platt MS. Neonatal Haemophilus vaginalis (Corynebacterium vaginale) infection. Clin Pediatr (Phila) 1971;10:513-6.

29. Carney FE. Haemophilus vaginalis septicemia. Obstet Gynecol 1973;41:78-9.

30. Monif GRG, Baer H. Haemophilus (Corynebacterium) vaginalis septicemia. Am J Obstet Gynecol 1974;120:10415.

31. Reimer LG, Relter LB. Gardnerella vaginalis bacteremia: a review of thirty cases. Obstet Gynecol 1984;64:170-2.

32. Abercrombie GF, Allen J, Maskell R. Corynebacterium vaginale urinary-tract infections in a man. Lancet 1978;i:766.

33. Finkelhor RS, Wolinsky E, Kim CH, Tchou P, Frengley JD. Gardnerella vaginalis perinephric abscess in a transplanted kidney. N Engl J Med 1981;304:846.

34. Loulerge J, Laudat P, Huten N, Raoult A, Boutault L. Upper urinary tract infection with Gardnerella vaginalis in a woman. Eur J Clin Microbiol 1984;3:270.

35. Fairley KF, Birch DF. Unconventional bacteria in urinary tract disease: Gardnerella vaginalis. Kidney Int 1983;23:862-5.

36. Johnson AP, Davies HA. Demonstration by electron microscopy of pili on Gardnerella vaginalis. British Journal of Venereal Diseases 1984;60:196-7.

37. Ison CA, Easmon CSF. Studies on the mechanism of adhesion of Gardnerella vaginalis to human erythrocytes. Scand J Urol Nephrol 1985;suppl 86:191-3. 